\title{
LISTENING COMPREHENSION STRATEGIES EMPLOYED BY EFL TERTIARY STUDENTS IN CHINA: A CASE STUDY
}

\author{
Chen Xiao \\ Faculty of Education, SEGi University; Kota Damansara, Selangor, Malaysia. \\ Katherine.xiao@163.com \\ Gurnam Kaur Sidhu \\ Faculty of Education, SEGi University, Kota Damansara, Selangor, Malaysia. \\ gurnamgurdial@segi.edu.my
}

\begin{abstract}
Listening comprehension is often a neglected and forgotten skill in most EFL and ESL classrooms. Therefore, the main aim of this case study was to investigate the listening comprehension strategies employed by EFL tertiary students in China. The study involved a total of 360 undergraduate students studying English as foreign language in an institution of higher learning in China. Data was collected via a survey and semi-structured interviews. The findings revealed that metacognitive strategies were the more frequently used strategies followed by cognitive and socio-affective strategies. The study also found that female students used more listening strategies than males and there was a positive correlation between listening comprehension strategy use and language proficiency. Finally, the study revealed that there were significant differences among the three types of strategies employed by students based on language proficiency. These findings have implications for language instructors teaching listening comprehension in their EFL classrooms.
\end{abstract}

Keywords: listening comprehension strategies, cognitive strategies, metacognitive strategies, socioaffective strategies

\section{Introduction}

A language is generally taught and assessed based on the four main language skills of listening, speaking, reading and writing. Of these four skills, listening being a receptive skill, is considered as a skill that can be acquired naturally through speaking and reading (Lau, 2015), so it is often ignored or poorly taught in most classroom where English is taught as a Second Language (ESL, hereafter) or as a Foreign Language (EFL, hereafter) classrooms (Vandergrift, 1997). In fact, the latest research in listening comprehension highlights the fact that listening comprehension is problematic for many EFL learners and hence instructors should view it as a cornerstone and foundation for success in language learning (Kassem, 2015). Therefore, language instructors need to help learners develop listening comprehension strategies with the aim not only to enhance the comprehensible input and also improve the development of other language skills.

Listening comprehension strategies are defined as "conscious plans to manage incoming speech, particularly when the listener knows that he/she must compensate for incomplete input or partial understanding" (Rost, 2011, p236). They are categorized as cognitive, metacognitive, and socioaffective strategies, which focuses on solving the problems of learners' acquisition, storage, retrieval and use of information (Vandergrift, 1997). Cognitive strategies are separate learning activities (Serri, Boroujeni and Hesabi, 2012) to manage the learning tasks or complete a particular task, involving inferencing, elaboration, summarization, translation, transfer, repetition, resourcing, grouping, notetaking, substitution and deduction/induction (Vandergrift, 1997). Metacognitive strategies are "the ability of learners to control their thoughts and to regulate their own learning" (Vandergrift and Goh, 2012, p5), including planning, monitoring, evaluation and problem identification (Vandergrift, 1997). Socio-affective strategies are activities to strengthen positive emotional attitudes toward language learning (Chamot and O'Malley, 1987). They can be divided into five categories: questioning for 
clarification, cooperation, lowering anxiety, self-encouragement and taking emotional temperature (Vandergrift, 1997).

Of these listening comprehension strategies, metacognitive strategies can assist learners to activate their thinking and improve their learning performance in most cases. They are not the theoretical orientation, but the methodology to cultivate the ability to self-regulated learning. Graham and Santos (2015) indicated that students would be able to control over their learning process if they have the opportunity to learn about the metacognitive strategy use.

Research on listening comprehension strategies have mainly focused on four aspects: (1) identify and classify strategies used by EFL/ESL learners; (2) investigate the frequency of strategies in different groups based on gender, language proficiency level; (3) examine the relationship between strategy use and different variable (e.g., anxiety, self-efficacy); (4) examine the reflection of strategy instruction on listening comprehension achievement (Kassem, 2015).

In China, English is taught as a compulsory foreign language in all universities, and students start to learn English either at primary or junior middle school. Nonetheless, the teaching of English often focuses on vocabulary, grammar and reading comprehension skills with listening been often neglected in the syllabus. Because assessment for listening is not included in National College Entrance Examination in some provinces (like Henan province), the teaching and learning of English concentrate more on reading and writing at both the primary and secondary schools levels. Likewise, there are also limited materials and courses on listening and speaking available for students before entering institutions of higher learning (IHL, hereafter). However, students need to master all the four language skills in college, especially listening skills as the lecture method is one of the common instructional method in the EFL classrooms in China. Therefore, there is a need to investigate the listening strategies used by EFL students in China, in order to provide the useful information for listening instruction in the classroom.

\section{The Study}

With listening been treated as the black sheep in most language classrooms, a deep understanding of strategies employed by EFL tertiary students in China can help researchers and teachers to seek for favorable programs to develop the listening instruction. To date, most previous studies in China have concentrated on examining the reflection of strategy instruction on listening comprehension achievement and the relationship between strategy use and different variables. Nevertheless, limited empirical studies have focused on listening strategies employed by EFL learners based on variables such as gender and different language proficiency levels in the EFL contexts in China. Therefore, this case study investigated the listening comprehension strategies employed by EFL students in China. The study was guided by the following three questions:

(1) What are the listening comprehension strategies employed by the EFL tertiary students in China?

(2) Are there any significant differences in the use of listening comprehension strategies based on gender?

(3) Are there any significant differences in the use of listening comprehension strategies based on EFL students' language proficiency?

The study involved a total of 360 EFL undergraduate students studying in an IHL located in Henan, China. These students were all freshmen and randomly selected from seven different faculties. Data in the study were collected via adapted version of two questionnaires-i.e. Listening Comprehension Strategy Questionnaire (LCSQ, hereafter) from the LCSUI (Listening Comprehension Strategy Use Inventory) in Ishler (2010) and MALQ (Metacognitive Awareness Listening Questionnaire) in Vandergrift (1997). Data were analyzed using both descriptive and inferential statistics such as frequency, percentages, means, t-tests and analysis of variance (ANOVA) which were analyzed using the SPSS (version 22). The Cronbach alpha values obtained from cognitive strategies, metacognitive strategies and socio-affective strategies were $0.894,0.789$ and 0.755 respectively, and the reliability of the LCSUI recorded a high reliability (0.922). All these scores indicate a high degree of internal consistency and reliability for the instrument used because a reliability coefficient of 0.70 or above is acceptable (Dörnyei 2007).

On the other hand, semi-structured interviews were conducted with 12 volunteers. The qualitative data obtained were analyzed using both inductive and deductive analysis to answer the three questions posed in the study. 


\section{Results and Discussion}

This section provides the findings to the research questions followed by the interpretation of the findings on listening comprehension strategy use among Chinese EFL tertiary students.

\subsection{Listening comprehension strategy use}

The first research question explored the listening comprehension strategy use among EFL tertiary students in China. The findings are presented in the Table 1 which shows the overall mean and standard deviation of strategy use among EFL students.

Table 1 Listening Comprehension Strategy Use $(n=360)$

\begin{tabular}{c|c|c}
\hline & $\mathrm{M}$ & $\mathrm{SD}$ \\
\hline Cognitive strategies & 3.16 & 0.56 \\
\hline Metacognitive strategies & 3.27 & 0.50 \\
\hline Socio-affective strategies & 2.76 & 0.54
\end{tabular}

Scale: Never $=1 ;$ Rarely $=2 ;$ Sometimes $=3 ;$ Frequently $=4 ;$ Always $=5$

Based on the findings, it can be seen that the metacognitive listening strategies were the most frequently used strategies $(\mathrm{M}=3.27, \mathrm{SD}=0.50)$, followed by cognitive listening strategies $(\mathrm{M}=3.16$, $\mathrm{SD}=0.56)$. The socio-affective listening strategies recorded the lowest mean value $(\mathrm{M}=2.76, \mathrm{SD}=0.54)$. The findings reveal that Chinese EFL students frequently use meta- cognitive strategies and these strategies are important for successful listening because metacognitive strategies can help students plan, monitor and evaluate their listening process (Vandergrift, 1997). The Chinese EFL students recorded the infrequent use of socio-affective strategies. The possible explanation is that these strategies need to be encouraged in the listening classroom. According to Riazi (2007), the instructor plays an important role in encouraging learners to use social and affective strategies, compared with other strategies. The same pattern was reported by Bidabadi and Yamat (2011) who noted that EFL freshman university students' rarely used socio-affective strategies. However, a few studies have recorded cognitive strategies as the frequently used strategies followed by metacognitive strategies with socio-affective strategies been the least frequently employed strategies (e.g, Serri, Boroujeni and Hesabi, 2012; Mohseny and Raeisi, 2009).

\subsubsection{Cognitive strategies}

Cognitive strategies assist learners to process the information by rehearsing, organizing and inferring. Of all the sub-strategies, the strategy of transfer $(\mathrm{M}=3.61, \mathrm{SD}=0.984)$ was used most frequently used, followed by translation $(\mathrm{M}=3.44, \mathrm{SD}=1.093)$. This implies that students tend to employ more transfer and translation strategies and this shows that L1 knowledge plays an important role in the processing of L2 listening comprehension. Interview sessions also revealed that a majority of Chinese EFL students often resort to translating the words and sentences that they hear into Chinese when they do not completely understand a paragraph. The interviews also showed that these students often use Chinese linguistic knowledge to group the known meaning of words and sentences to construct the meaning of the paragraph. Some students also reported they would first translate the words and phrases into Chinese and then attempt to make connections using the words into a sentence based on Chinese grammar principles. In addition, grouping $(\mathrm{M}=2.67, \mathrm{SD}=1.053)$ and substitution $(\mathrm{M}=2.57, \mathrm{SD}=1.053)$ were the least frequently employed cognitive strategies among the respondents. Grouping and substitution strategies both require some knowledge in English and since these EFL students often resort to translating and with their limited knowledge in English they are probably not able to use these strategies effectively in their listening comprehension classes.

\subsubsection{Metacognitive strategies}

Metacognitive strategies are strategies that can help students to plan, monitor, evaluate and identify the problems in the listening comprehension process. Results are displayed in the Table 2 below.

Table 2 Metacognitive Listening Strategy Use $(n=360)$

\begin{tabular}{l|c|c|c}
\hline \multicolumn{1}{c|}{ Sub-strategies } & M & SD & Ranking \\
\hline Planning & 3.35 & 0.55 & 1 \\
\hline
\end{tabular}




\begin{tabular}{l|l|l|l}
\hline Monitoring & 3.33 & 0.72 & 2 \\
\hline Evaluation & 3.30 & 0.61 & 3 \\
\hline Problem identification & 2.85 & 0.89 & 4 \\
\hline
\end{tabular}

Scale: Never $=1 ;$ Rarely $=2 ;$ Sometimes $=3 ;$ Frequently $=4 ;$ Always $=5$

The findings showed that planning was the most frequently employed metacognitive strategy $(\mathrm{M}=3.35)$ followed by monitoring and evaluation. The least frequently used strategy was problem identification $(\mathrm{M}=2.85)$. These findings reveal that students have the awareness to think about an appropriate action plan to complete the listening tasks and they can monitor themselves. This is good as it reveals they are to a certain extent capable to taking some ownership of their learning. Nevertheless, evaluation and problem identification are their least frequently used listening comprehension strategies. This concern was also articulated during the interview sessions. Students said that they often found it difficult to monitor themselves. For example, Student B highlighted that she was not able to monitor herself 'because I am not sure if what I have done during listening is right or wrong and. . when I ask my friend they also do not know." The interview sessions also revealed that students had issues in problem identification. For instance, Student D stressed that "when I am doing listening and if I did something wrong I am not able to find out where I went wrong and why I was wrong . . . so I think listening to English is very difficult for me."

\subsubsection{Socio-affective strategies}

Socio-affective strategies help learners to understand the listening text by cooperation, asking questions and lowering anxiety. The mean value of lowering anxiety was $2.94(\mathrm{SD}=0.58)$ that was more than other values, that was, lowering anxiety was used most frequently by students. The frequency of cooperation use was the lowest $(\mathrm{M}=2.50, \mathrm{SD}=0.89)$. These results are presented in the Table 3 below.

Table 3 Socio-affective Listening Strategy Use $(n=360)$

\begin{tabular}{c|c|c|c}
\hline Sub-strategies & M & SD & Ranking \\
\hline Lowering anxiety & 2.94 & 0.58 & 1 \\
\hline Self-encouragement & 2.87 & 0.90 & 2 \\
\hline Taking emotional temperature & 2.81 & 1.17 & 3 \\
\hline Questioning for clarification & 2.60 & 0.96 & 4 \\
\hline Cooperation & 2.50 & 0.89 & 5 \\
\hline
\end{tabular}

Scale: Never $=1 ;$ Rarely $=2 ;$ Sometimes $=3 ;$ Frequently $=4 ;$ Always $=5$

The results showed that students could reduce their anxiety and encourage themselves. Students A and $\mathrm{B}$ pointed that they usually self-question themselves to test their understanding use relaxing strategies when they feel nervous. A majority of the students, however, revealed that they rarely used cooperative strategies and this was also highlighted during interview sessions. Respondent $\mathrm{C}$ reiterated that she seldom worked with other students to complete listening tasks as the classroom provided very few opportunities for such collaboration. The limited use of cooperative strategies is also probably because of the large class enrolment in the university concerned. In this university EFL classes comprise approximately 60 students and the listening activities are conducted as mass lectures where there are very limited activities for cooperative learning due to logistics issues. Another possible reason may be due to the fact that the Chinese often regard completing assignments independently, a good learning strategy for students. Hence teachers seldom arrange for group assignments both within and outside the class resulting in students rarely using cooperative listening strategies.

\subsection{Listening Comprehension Strategy Use Based on Gender}

In order to examine if there were any significant differences in the use of listening comprehension strategies based on gender, an independent-sample T-test was used and the results are presented in Table 4. 
Table 4 Listening Comprehension Strategy Use Based on Gender $(\mathrm{p} \leq 0.05)$

\begin{tabular}{l|c|c|c|c|c|c}
\hline \multirow{2}{*}{$\begin{array}{l}\text { Listening } \\
\text { Strategies }\end{array}$} & \multicolumn{2}{|c|}{ Male $(\mathrm{n}=134)$} & \multicolumn{2}{|c|}{ Female $(\mathrm{n}=226)$} & \multirow{2}{*}{ T-value } & Sig. (2-tailed) \\
\cline { 2 - 7 } & $\mathrm{M}$ & $\mathrm{SD}$ & $\mathrm{M}$ & $\mathrm{SD}$ & & \\
\hline Cog & 3.11 & 0.56 & 3.18 & 0.56 & -1.149 & 0.251 \\
\hline Meta & 3.23 & 0.49 & 3.28 & 0.51 & -0.913 & 0.362 \\
\hline SoA & 2.72 & 0.57 & 2.77 & 0.52 & -0.910 & 0.363 \\
\hline
\end{tabular}

Scale: Never $=1 ;$ Rarely $=2 ;$ Sometimes $=3 ;$ Frequently $=4 ;$ Always $=5$

From the findings it can be seen that female students employ slightly more listening comprehension strategies than male students in all three listening comprehension categories, i.e. cognitive strategies $(\mathrm{M}=3.18>3.11)$, metacognitive strategies $(\mathrm{M}=3.28>3.23)$ and socio-affective strategies $(\mathrm{M}=2.77>2.72)$. Of all the three kinds of strategies, the most frequently used strategies between both male and female students were metacognitive strategies. However, the t-test results showed that there were no significant differences in the use of these strategies (cognitive strategies: $t=-1.149$, $\mathrm{p}=0.251>0.05$; metacognitive strategies: $\mathrm{t}=-0.913, \mathrm{p}=0.362>0.05$; socio-affective strategies: $\mathrm{t}=-0.910$, $\mathrm{p}=0.363>0.05$ ).

These results support findings from other research findings on language learning strategies (Green and Oxford, 1995; Alhaysony, 2017). In addition, Fayyaz and Kamal (2014) investigated 314 learners from the age group of 18 to 30 and found that there were significant differences in strategy use between males and females with the women employing significantly more metacognitive listening strategies. The possible causes may be that females generally display greater social orientation than males, and so they are more willing to take part in the social activities. Furthermore, female behaviors are said to be gentler so that they are more cooperative and less competitive than males (Oxford, Nyikos and Ehrman, 1988).

\subsection{Listening Comprehension Strategy Use Based on Language Proficiency}

To investigate the frequency use of listening comprehension strategy use among respondents with varying levels of language proficiency, the respondents were divided into three groups, i.e. high English language proficiency (HEP), average English language proficiency (AEP) and limited English language proficiency (LEP), based on their English Language achievements in their National College Entrance Examination in China (NCEE). Out of the total 360 respondents who completed the questionnaires in the study, HEP group comprised 120 respondents and their English language scores ranged from 132 to 105 marks out of a total score of 150. AEP group consisted of 118 respondents with language scores ranging from 104 to 92 marks whilst the LEP students (122) obtained below 92 marks. To examine if there were any significant difference in strategy use based on language proficiency, a one-way ANOVA was applied to analyze the data. The ANOVA results are indicated in the Table 5.

Table 5 Listening Comprehension Strategy Use Based on Language Proficiency $(\mathrm{p} \leq 0.05)$

\begin{tabular}{c|c|c|c|c|c}
\hline \multirow{2}{*}{$\begin{array}{c}\text { Listening } \\
\text { Strategies }\end{array}$} & \multicolumn{3}{|c|}{$\mathrm{M}$} & \multirow{2}{*}{ F } & Sig. \\
\cline { 2 - 5 } & HEP $(\mathrm{n}=120)$ & AEP $(\mathrm{n}=118)$ & LEP $(\mathrm{n}=122)$ & & \\
\hline Cog & 3.26 & 3.16 & 3.05 & 4.411 & 0.013 \\
\hline Meta & 3.40 & 3.25 & 3.15 & 8.340 & 0.000 \\
\hline SoA & 2.83 & 2.79 & 2.64 & 4.324 & 0.014 \\
\hline
\end{tabular}

From the results presented in the Table 5 , it can be seen that there is a positive correlation between language proficiency and listening comprehension strategy use. That is, the higher the students' language proficiency, the more frequency use of listening comprehension strategies was seen. Moreover, metacognitive strategies were again the most frequently used strategy among the three groups whilst the socio-affective strategies were the least frequently used strategies in the three groups. Besides that, there were significant differences among the three types of strategies employed by students with different language proficiency (cognitive strategies: $F=4.411, p<0.05$; metacognitive strategies: $\mathrm{F}=8.340, \mathrm{p}<0.05$; socio-affective strategies: $\mathrm{F}=4.324, \mathrm{p}<0.05)$. The results supported research findings of other studies conducted by Goh (1998) as well as Bidabadi and Yamat (2011). 


\section{CONCLUSIONS}

From the findings in this study, it can be summarized that EFL Chinese students in this study tend to use metacognitive listening strategies more frequently compared to cognitive and socio-affective listening comprehension strategies. In terms of metacognitive strategies these EFL students use planning and monitoring strategies more frequently compared to evaluating strategies. These students also rarely used problem identification strategies. This finding corroborates with findings presented in Sidhu (2003) who pointed out that ESL students lacked monitoring and evaluating strategies. Henceforth, language instructors need to ensure students are provided with sufficient listening activities where students are provided opportunities to self-evaluate and peer evaluate their listening performance. When students are well equipped with monitoring and evaluative metacognitive strategies, they will find it easier to identify their listening comprehension problems. In the long run, students will be able to internalize these three metacognitive strategies resulting in enhanced listening comprehension.

The current study also revealed that the most frequently used cognitive strategies among the EFL Chinese students were transfer and translation whilst grouping and substitution strategies left much to be desired. Students may pay more attention to the connection between Chinese and English, but they tend to ignore the internal connection in the language itself. Hence, the EFL listening classrooms in China need to provide more opportunities where students will learn to internalize not only the rules but more importantly process meaning from incoming speech flow during listening comprehension by thinking and making connections with English (L2) and not the first language (L1).

The findings also showed that the least frequently used strategies were the socio-affective strategies. This could be due to the cultural factor in EFL classrooms in China where learning is rather competitive and learning tasks are often completed on an individual basis. It is perhaps timely that EFL language instructors in China realize that language learning is a social process and it requires a lot of opportunities for students to listen and speak the language. Therefore, various listening activities that encourage cooperative and collaborative learning need to be integrated in the listening comprehension classroom. Activities such as triangle-listening, think-pair and snowballing should be a part and parcel in the listening classroom.

The findings in this study also revealed that though female students used more listening strategies, there was no significant differences in the use of listening comprehension strategies between male and female respondents. Furthermore, the findings also showed that there was a positive correlation between listening comprehension strategy use and language proficiency. Moreover, there were significant differences among the three types of strategies employed by students with different language proficiency with students with higher English proficiency using more strategies compared to students with average and limited language proficiency. Hence, teachers could design and arrange the different listening comprehension tasks or activities with different levels, and then students could choose to complete the corresponding tasks or activities with their abilities, which can reduce the students' anxiety and enhance their self-confidence, especially for LEP students.

Last but not least, it is perhaps important to stress that for more effective employment of strategy use, the EFL instructors need to put into plan an effective strategy training programme. For example, Selamat and Sidhu (2011) in their study initiated a metacognitive strategy instruction programme (MeTSi) which witnessed enhanced listening comprehension strategies among the tertiary students in Malaysia.

Finally, it cannot be denied that this case study has a number of limitations. The small sample involving only seven faculties in one university does not give us a true picture of listening comprehension strategy use in the EFL classrooms in China. Moreover, the data was only collected via a self-perception survey and a few interviews. Both these instruments have their own limitations as respondents may have provided socially accepted responses. Despite these limitations, this case study has shed some lights into the listening comprehension strategy use in the EFL classrooms in China. Consequently, EFL instructors can take steps to enhance listening comprehension among their learners. 


\section{REFERENCES}

Alhaysony, M. (2017). Language Learning Strategies Use by Saudi EFL Students: The Effect of Duration of English Language Study and Gender. Theory and Practice in Language Studies, 7(1): $18-28$.

Bidabadi, F. S. and Yamat, H. (2011). The Relationship between Listening Strategies Used by Iranian EFL Freshman University Students and Their Listening Proficiency Levels. English Language Teaching, 4(1): 26-32.

Chamot, A. U. and O'Malley, J. M. (1987). The Cognitive Academic Language Learning Approach: A Bridge to the Mainstream. TESOL Quarterly, 21(2): 227-249.

Dörnyei, Z. (2007). Research Methods in Applied Linguistics: Quantitative, Qualitative, and Mixed Methodologies, OUP Oxford, Oxford.

Fayyaz, W. and Kamal, A. (2014). Role of gender, age, and geographical locality in metacognitive listening skills of English as a foreign language. Pakistan Journal of Psychological Research, 29(2): 265-276.

Goh, C. C. M. (1998). How ESL learners with different listening abilities use comprehension strategies and tactics. Language Teaching Research, 2(2): 124-147.

Graham, S. \& Santos, D. (2015). Strategies for Second Language Listening: Current Scenarios and Improved Pedagogy. Palgrave Macmillan, London.

Green, J. M. and Oxford, R. (1995). A closer look at learning strategies, L2 proficiency, and gender" TESOL Quarterly, 29(2): 261-297, (1995).

Ishler, J. M. (2010). The listening strategies of Tunisian university EFL learners: A strategy based approach to listening to oral English texts. PhD Thesis, Indiana University of Pennsylvania, Indiana, PA. December. See also URL https://search.proquest.com/docview/839878269? accountid $=50955$.

Kassem, H. M. (2015). The Relationship Between Listening Strategies Used by Egyptian EFL College Sophomores and Their Listening Comprehension and Self-Efficacy. English Language Teaching, 8(2): 153-169.

Lau, K.-L. (2016). Strategy use, listening problems, and motivation of high-and low-proficiency Chinese listeners. The Journal of Educational Research, 110(5): 503-514.

Mohseny, A. and Raeisi, N. (2009). The relationship between language proficiency of EFL students and their strategy use in listening comprehension. Journal of Teaching English as a Foreign Language and Literature, 1(4): 111-132.

Oxford, R., Nyikos, M. and Ehrman, M. (1988). Vive la difference? Reflections on sex differences in use of language learning strategies. Foreign Language Annals, 21(4): 321-329.

Riazi, A. (2007). Language learning strategy use: Perceptions of female Arab English majors. Foreign Language Annals, 40(3): 433-440.

Rost, M. (2011). Teaching and researching: Listening (2nd ed.). Taylor \& Francis, New York.

Selamat S. and Sidhu, G. K. (2011). Students' Perceptions of Metacognitive Strategy Use in Lecture Listening Comprehension Language Education in Asia, 2 (2), 165 - 198.

Serri, F., Boroujeni, A. J. and Hesabi, A. (2012). Cognitive, metacognitive, and social/affective strategies in listening comprehension and their relationships with individual differences. Theory and Practice in Language Studies, 2(4): 843-849.

Sidhu, G. K. (2009). Empowering Learners through Strategy Training. In S.M. Thang \& B. Sinclair. Learner Autonomy: Research and Practice in Malaysia and Singapore. Pearson Malaysia, Petaling Jaya, Malaysia. Chapter. 5, pp. 106-134.

Vandergrift, L. (1997). The comprehension strategies of second language (French) listeners: A descriptive study. Foreign Language Annals, 30(3): 387-409.

Vandergrift, L. and Goh, C. C. M. (2012). Teaching and learning second language listening: Metacognition in action. Routledge, New York. 